\title{
Tindak tutur dalam teks kepewaraan
}

\author{
Bakdal Ginanjar ${ }^{1}$, Hesti Widyastuti ${ }^{2}$, Hanifullah Syukri ${ }^{3}$ \\ Universitas Sebelas Maret ${ }^{1,2,3}$ \\ 1Correspondence: bakdalginanjar@staff.uns.ac.id
}

\begin{abstract}
This study examines the speech acts contained in the text of citizenship. This speech act is very typical considering the objectives to be achieved by the text are different from other texts. This research is a descriptive qualitative type in linguistics. Data in the form of speech pewara. Data is taken from the text of the prisoners in the civil training at Perum. Graha Jati Indah, Jati, Jaten, Karanganyar, Central Java. Data was taken by listening, recording, and note taking. Data were analysed using the pragmatic equivalent method. The results of the analysis show that the narration uses illocutionary speech in the form of assertive, directive, commissive, and expressive.
\end{abstract}

Keywords: speech acts, illocution, pewara

\section{Pendahuluan}

Salah satu alat ukur dari kesuksesan atau keberhasilan dalam aktivitas komunikasi sebagai pembawa acara atau lazim dikenal dengan istilah pewara adalah lancar dan selesainya susunan acara dan berbagai hal yang dibawakannya selama acara berlangsung. Kelancaran mengomunikasikan berbagai hal dengan bahasa yang baik dan penampilan yang menarik di depan umum dapat dijadikan sebagai indikator keberhasilan dalam kegiatan membawakan atau mengendalikan sebuah acara.

Namun, yang menjadi persoalan dalam konteks yang demikian itu bagaimana cara menjadi seorang pewara yang menarik sekaligus kreatif. Dalam kondisi sekarang ini, seorang pewara yang baik tidaklah cukup untuk menjadikan jalannya sebuah acara menjadi baik pula. Dalam hal ini, aspek kreatif dari pewara sangat diperlukan dalam mengomunikasikan berbagai hal. Beberapa saat lalu pada awal 2019, dapat disaksikan di layar televisi nasional bagaimana performa seorang pewara dalam memimpin sebuah acara debat calon Presiden Republik Indonesia yang mendapat banyak perhatian dari khalayak luas. Artinya, kemampuan berkomunikasi seorang pewara kepada pendengar/penonton amatlah penting. 
Beberapa penelitian terkait yang membahas tentang penggunaan tindak tutur dalam sebuah konteks yang hanya memungkinkan beberapa pihak saja yang dapat berperan sebagai penutur utama di antaranya dilakukan oleh Sibarani (2008), Wati, et.al. (2017), dan Nifmaskossu, et.al. (2019). Penelitian Sibarani (2008) mengambil latar pada upacara perkawinan masyarakat Batak Toba. Sementara itu, Wati, et.al. (2017) mengangkat latar di sebuah pembalajaran pada sekolah menengah atas. Di pihak lain, Nifmaskossu, et.al. (2019) mengkaji pada upacara perkawinan adat masyarakat Watumuri. Meskipun penelitian-penelitian tersebut membahas tentang tindak tutur dalam sebuah situasi yang kurang lebih sama dengan kajian ini, perbedaan konteks atas peran penutur dibandingkandengan penutur pada penelitian sebelumnya dalam sebuah percakapan, dalam hal ini kedudukan pewara dalam sebuah acara, akan dapat membedakan hasil penelitian yang diperoleh secara signifikan.

Sehubungan dengan hal itu, permasalahan muncul ketika seseorang yang belum atau jarang untuk berperan sebagai pewara mengemban tugas tersebut. Permasalahan pada aspek keterampilan berbahasa sangat menonjol tergambar dalam situasi demikian. Untuk itu, perlu adanya pengetahuan berbagai tindak tutur apa yang dapat dimanfaatkan ketika pewara tampil. Hal ini dimungkinkan karena setiap teks akan berbeda dengan teks lainnya sesuai dengan tujuan masing-masing yang ingin dicapai. Untuk itu, tulisan ini akan mengkaji tindak tutur yang dipakai pewara dalam teks yang dibawakannya dari sudut pandang pragmatik.

Salah satu definisi pragmatik yang dibuat oleh Levinson (1983, hlm. 9) bahwa pragmatik adalah studi tentang relasi antara bahasa dan konteks, konteks itu telah tergramatisasi dan terkodifikasi dalam struktur sebuah bahasa. Definisi ini menegaskan bahwa konteks sebuah tuturan telah tergramatisasi dan terkodifikasi dalam sebuah bahasa sehingga tidak dapat dilepaskan dari struktur kebahasaannya. Jadi, sebuah analisis bahasa tidak bisa dilepaskan dari konteksnya.

Teori tindak tutur memandang tuturan sebagai tindakan (Sbisa dalam Verschueren, Ostman, dan Blommaert (ed.), 1995, hlm. 497). Tuturan merupakan produk penggunaan bahasa dalam bentuk lisan atau tulisan melalui struktur linguistik yang berhubungan atau tidak pada kalimat. Adapun tindakan adalah sesuatu yang dilakukan oleh seseorang secara aktif. Searle (1974, hlm. 16) mengemukakan bahwa lebih tepatnya, produksi atau pengeluaran suatu kalimat di bawah kondisi-kondisi tertentu adalah tindak tutur, dan tindak tutur (dengan jenis tertentu untuk dijelaskan kemudian) adalah dasar atau unit minimal linguistik komunikasi. Dalam linguistik komunikasi, bahasa bukan sekadar simbol, kata, atau kalimat, melainkan sebuah produk dari simbol, kata, atau kalimat dalam kondisi atau konteks tertentu dan terwujud sebagai tindak tutur. Senada dengan pendapat tersebut, Allan (1986, hlm. 164) menegaskan 
bahwa bahasa itu menjadi ada hanya karena seseorang melaksanakan tindak bertutur atau menulis, yaitu ketika pembicara membuat suatu tuturan kepada pendengar dalam konteks. Pendapat ini merumuskan bahwa tindak tutur terjadi ketika penutur membuat tuturan kepada mitra tutur dalam sebuah konteks.

Austin (1968, hlm. 94-107) membagi tindak tutur menjadi tiga, yaitu tindak lokusi, tindak ilokusi, dan tindak perlokusi. Tindak lokusi adalah melakukan tindakan untuk mengatakan sesuatu. Tindak tutur ini semata-mata hanya menuturkan sebuah kalimat yang bermakna penuh. Austin (1968, hlm. 108) mengatakan bahwa kami menyimpulkan bahwa dengan mengatakan kami melakukan tindak lokusi, yang secara kasar setara dengan menuturkan sebuah kalimat dengan arti dan referen tertentu, yang sekali lagi setara dengan makna dalam arti tradisional. Pernyataan tersebut menegaskan bahwa tindak lokusi mempermasalahkan makna harfiah sebuah kalimat yang dituturkan. Oleh sebab itu, pemahaman terhadap tindak lokusi harus didasarkan pada tata bahasa, leksikon, semantik, dan fonologi suatu bahasa (Allan dalam Asher dan Simpson (ed.), 1994, hlm. 41-42). Jadi, tindak lokusi dapat dipahami tanpa mempertimbangkan konteks yang hadir.

Tindak ilokusi adalah melakukan suatu tindakan dalam mengatakan sesuatu. Austin (1968, hlm. 99) mengatakan bahwa suatu tindak ilokusi adalah melakukan tindakan dalam mengatakan sesuatu yang berlawanan dengan melakukan tindakan mengatakan sesuatu. Tindak ini berbeda dengan tindak lokusi karena memiliki daya (force), misalnya melapor, memeritah, dan mengancam. Ketiga contoh itu dinamakan daya ilokusi (illocutionary force).

Tindak ilokusi mempermasalahkan maksud penutur dalam sebuah tuturan (Searle, 1974, hlm. 42-50; Gunarwan (dalam Purwo (ed.), 1994, hlm. 84-85. Maksud dibedakan dengan makna. Maksud adalah unsur luar bahasa yang berada di pihak penutur, sedangkan makna adalah unsur dalam bahasa (Verhaar, 2001, hlm. 129-131). Karena berada di luar bahasa, maksud hanya dapat diketahui jika mengaitkan tuturan dengan konteksnya. Tindak ilokusi berhubungan langsung dengan tuturan performatif, yaitu tuturan yang menyebut dirinya sendiri dan mengacu pada tindakan yang dilakukan penutur ketika berbicara (Austin, 1968, hlm. 12-13). Tuturan ini dapat berlangsung bila tiga buah syarat yang disebut felicity conditions terpenuhi (Austin, 1968, hlm. 14-15).

a. Peserta tutur dengan situasi pertuturannya harus sesuai.

b. Tindakan harus dilakukan secara sungguh-sungguh oleh peserta tutur.

c. Peserta tutur harus memiliki niat yang sungguh-sungguh untuk melakukan tindakan. 
Pemahaman mitra tutur terhadap maksud penutur atau tindak ilokusi dinamakan efek ilokusi (Searle, 1974, hlm. 47). Efek ilokusi bukanlah suatu respons atau tanggapan, tetapi berupa pemahaman mitra tutur terhadap tuturan yang disampaikan penutur, misalnya berjanji adalah tindak ilokusi dan pemahaman mitra tutur terhadap tindak itu merupakan efek ilokusi. Pemunculan efek itu dilatarbelakangi oleh kenyataan bahwa tidak semua tindak ilokusi memiliki efek perlokusi (Searle, 1974, hlm. 46).

Tuturan yang menghasilkan efek atau pengaruh kepada mitra tutur digolongkan sebagai tindak perlokusi atau efek perlokusi. Tindak perlokusi adalah melakukan suatu tindakan dengan menyatakan sesuatu. Austin (1968, hlm. 101) mengemukakan bahwa mengatakan sesuatu akan sering, atau bahkan secara normal, menghasilkan konsekuensi efek tertentu pada perasaan, pemikiran, atau tindakan pendengar. Efek perlokusi merupakan respons atau tanggapan mitra tutur terhadap maksud penutur yang dapat berwujud respons fisik, verbal, atau mental.

Austin (1968, hlm. 120) menyebut tindak ilokusi sebagai tindak konvensional, sedangkan tindak perlokusi bukan tindak konvensional. Kekonvensionalan tindak ilokusi ditunjukkan oleh formula tuturan performatif.

Searle (dalam Martinich (ed.), 1996, hlm. 147-149) mengklasifikasikan tindak ilokusi menjadi lima jenis, yakni asertif, direktif, komisif, ekspresif, dan deklarasi. Dasar utama pengklasifikasiannya adalah titik ilokusi (illocutionary point) atau tujuan ilokusi. Asertif adalah tindak tutur yang mengikat penutur pada kebenaran proposisi yang diungkapkannya, misalnya menyatakan, melapor, dan memprediksi. Direktif adalah tindak tutur yang membuat mitra tutur melakukan sesuatu, misalnya memohon, memerintah, dan meminta. Komisif adalah tindak tutur yang mengikat penutur pada suatu tindakan yang akan dilakukannya pada masa mendatang, misalnya berjanji dan bersumpah. Ekspresif adalah tindak tutur yang mengungkapkan sikap psikologis penutur terhadap suatu keadaan, misalnya memaafkan, memuji, dan berterima kasih. Deklarasi merupakan jenis ilokusi yang bersifat khas, yakni keberhasilan melakukan ilokusi ini akan menghubungkan antara isi proposisi dan realitas di dunia. Untuk itu, penutur deklarasi haruslah seseorang yang mempunyai kekuasaan atau wewenang khusus dalam sebuah institusi tertentu, misalnya hakim dalam institusi pengadilan menjatuhkan hukuman.

Dari beberapa pandapat di atas, tuturan yang dipakai secara konkret terwujud sebagai sebuah tindak tutur. Penutur dalam mengekspresikan tuturan tidak semata-mata mengatakan sesuatu. Dalam pengucapan ekspresi itu, penutur juga melakukan atau menindakkan sesuatu. Demikianlah, aktivitas mengujarkan atau menuturkan tuturan dengan maksud tertentu itu merupakan tindak tutur (speech act).

Tindak tutur ini memiliki maksud dan tujuan-tujuan tertentu yang dapat diketahui dengan memperhitungkan konteks pemakaiannya. Secara umum, 
tindak tutur dibagi menjadi tiga, yaitu lokusi, ilokusi, dan perlokusi. Tindak lokusi adalah tindak bertutur dengan kata, frase, dan kalimat sesuai dengan makna yang dikandung oleh kata, frase, dan kalimat itu. Tindak ilokusi adalah tindak tutur melakukan sesuatu dengan maksud dan fungsi yang tertentu pula. Tindak perlokusi adalah tindak tutur menumbuhkan pengaruh kepada diri mitra tutur.

\section{Metode}

Penelitian ini berjenis kualitatif deskriptif dalam linguistik. Data berwujud tuturan pewara. Data diambil dari teks pewara dalam Pelatihan Kepewaraan di Perum. Graha Jati Indah, Jati, Jaten, Karanganyar, Jawa Tengah. Data diambil dengan metode simak, teknik rekam, dan teknik catat (Sudaryanto, 2015). Selanjutnya, data diklasifikasi berdasarkan jenis tindak tutur ilokusi yang muncul. Terakhir, Data dianalisis dengan menggunakan metode padan pragmatis (Sudaryanto, 2015).

\section{Hasil dan pembahasan}

Berdasarkan analisis data, ditemukan bermacam tindak tutur yang terbagi menjadi empat macam tindak tutur, yakni asertif, direktif, komisif, dan ekspresif. Setiap tindak tutur tersebut akan diuraikan secara terperinci di bawah ini. Data (1) merupakan tuturan yang di dalamnya terdapat ilokusi asertif.

1. Saya Mashud Manca Negara akan siap menemani Anda sampai dipenghujung acara nanti, tentunya dengan berbagai penampilan yang akan siap ditayangkan untuk kalian semua hahahah

2. Oia bapak ibuk perlu diiformasikan bahwa dipenghujung acara nanti ada atraksi sulap dari luar kota sumenep.

Data (1) menunjukkan adanyatindak asertif. Hal ini dimaksudkan oleh penutur untuk memberi tahu sesuatu kepada pendengar perihal isi acara. Hal ini dapat ditunjukkan oleh penanda akan siap menemani. Penanda tersebut bermaksud menginformasikan bahwa penutur berposisi sebagai pembawa acara sampai berakhirnya acara tersebut. Sementara itu, data (2) ditandai oleh pemarkah diinformasikan yang dituturkan oleh penutur.

Ilokusi direktif juga digunakandalam teks pewara. Hal itu ditunjukkan dalam tuturan (2) dan (3) di bawah ini. 
3. Pertama-tama sebelum memulai acara yang kita nantikan, mari kita panjatkan puji syukur kehadirat Allah SWT yang telah melimpahkan segala rahmat dan karunianya sehingga kita dapat berkumpul disini dalam keadaan sehat dan dapat mengikuti rangkaian acara yang ada.

4. Untuk membuat waktu yang lebih singkat, mari kita buka acara ini dengan mengucapkan basmallah.

Data (3) dan (4) mengandung tindak tutur direktif. Pada keduanya ilokusi tersebut berupa perintah kepada mitra tutur untuk melakukan suatu hal. Ilokusi tersebut ditandai dengan pemarkah lingual mari. Tindakan ini disampaikan secara langsung kepada mitra tutur.

Sementara itu, data yang menunjukkan penggunaan ilokusi komisif muncul pada data (5) dan (6) berikut.

5. Sebelum memulai acara, saya selaku pembawa acara akan memberitahukan susunan acara yang akan kita bersama lalui hari ini.

6. Sehubungan waktu, acara akan segera kita mulai.

Tuturan pada (5) dan (6) merupakan tuturan komisif. Hal ini ditandai dengan pemarkan akan. Maksud dari penutur adalah melakukan sesuatu di masa yang akan datang.

Tindak tutur lain yang muncul dalam teks pewara adalah tuturan ekspresif. Tuturan ini ditunjukkan dalam data (7) dan (8) berikut.

7. Makanya jangan kemana-mana karena dari berbagai penampilan malam ini sungguh sangat hebat tarianya dan sungguh gemulai goyangannya hahahah, oia bapak ibuk perlu diiformasikan bahwa dipenghujung acarananti ada atraksi sulap dari luar kota sumenep. Waw ..eksklusif banget lho ..

8. Duuh kerren, kayak fashion-fashion Korea lho.

Kedua data di atas menujukkan pemakaian tindak tutur ekspresif. Data (7) ditandai dengan penggunaan pemarkah eksklusif banget lho. Sementara itu, data (8) ditandai dengan pemarkan duhh kerren.

Berdasarakan analisis di atas, telah ditunjukkan berbagai tindak tutur dimanfaatkan oleh pewara dalam sebuah acara. Hasil ini menunjukkan adanya perbedaan dengan beberapa hasil kajian sebelumnya. Perbedaan tersebut diperlihatkan dengan adanya penggunaaan tindak tutur ekspresif oleh pewara. Hal itu berbeda dengan yang telah dinyatakan oleh Sibarani (2008), Wati, et.al. (2017), dan Nifmaskossu, et.al. (2019). Dalam penelitian Sibarani (2008), tindak tutur didominasi oleh tindak tutur menjelaskan yang masuk jenis tindak 
tutur asertif. Sementara itu, dalam penelitian Wati, et.al. (2017) ditunjukkan dominasi tindak tutur direktif dengan realisasi sebagai tindak tutur langsung. Sementara itu, dalam kajian Nifmaskossu, et.al. (2019) dihasilkan tuturan direktif munculsebagai tindak tutur dalam konteks upacara adat.

Berpijak dari hal tersebut, dapat dikatakan bahwa tindak tutur yang muncul tersebut dipengaruhi oleh konteks yang berada di seputaran pertuturan. Temuan tersebut sejalan dengan yang diungkapkan oleh Allan (1986). Hal selanjutnya yang perlu ditunjukkan dari analisis data bahwa jenis pertuturan memengaruhi munculnya berbagai tindak tutur. Sebut saja, pertuturan dalam situasi yang resmi akan memunculkan jenis tindak tutur yang berbeda dengan pertuturan yang semi formal, bahkan pada pertuturan yang tidak resmi.

\section{Kesimpulan dan saran}

Berdasarkan hasil analisis, dapat disimpulkan bahwa pewara sebagai penutur dalam sebuah acara memanfaatkan tindak tutur ilokusi yang meliputi asertif, direktif, komisif, dan ekspresif. Penggunaan ini didasarkan pada tujuan yang ingin dicapai oleh pewara dalam sebuah panggung atauacara tertentu. Hal ini juga menunjukkan bahwa tindak tutur ini akan berbeda dimanfaatkan dalam teks jenis lain dengan konteks situasi yang berbeda pula pastinya. Untuk itu,perludiadakan kajian tindak tutur dalam pemakaian bahasa di ranah lain untuk mendapat keberagaman pemakaian tindak tutur.

\section{Daftar rujukan}

Allan, K. (1986). Linguistic meaning (Volume 2). London: Routledge \& Kegan Paul.

- (1994). "Speech acts hierarchy locutions, illocutions, and perlocutions" dalam R.E. Asher dan J.M.Y. Simpson (ed.). The encyclopedia of language and linguistics (Volume 8). Oxford: Pergamon Press.

Asim G. (1994). "Kesantunan negatif di kalangan dwibahasawan indonesia-jawa di kakarta: kajian sosiopragmatik" dalam Bambang Kaswanti Purwo (ed.). Pellba 7. Yogyakarta: Kanisius.

Austin, J.L. (1968). How to do things with words. New York: Oxford University Press.

Levinson, S. C. (1983). Pragmatics. Cambridge: Cambridge University Press.

Nifmaskossu, R. et.al. (2019). Tindak tutur direktif upacara perkawinan adat masyarakat watumuri. Jurnal Pendidikan Bahasa dan Satra Indonesia, $8(1), 37-43$. 
Sbisa, M. (1995). "Speech act theory" dalam Jef Verschueren, Jan-Ola Ostman, dan Jan Blommaert (ed.). Handbook of pragmatics manual. Amsterdam: John Benjamins Publishing Company.

Searle, J. R. (1974). Speech acts: An essay in the philosophy of language. Cambridge: Cambridge University Press. . (1996). "A taxonomy of illocutionary acts" dalam A.P Martinich (ed.). The Philosophy of Language(Third Edition). New York: Oxford University Press.

Sibarani, T. 2008. Tindak tutur dalam upacara perkawinan masyarakat batak toba. Tesis. Medan: Universitas Sumetara Utara.

Sudaryanto. (2015). Metode dan aneka teknik analisis bahasa: Pengantar penelitian wahana kebudayaan secara linguistis. Yogyakarta: Duta Wacana University Press.

Wati, N.I, et.al. (2017). Tindak tutur direktif guru perempuan dalam pembelajaran bahasa Indonesia kelas XI SMA. Aksara: Jurnal Bahasa dan Sastra, 18(2), 100-112. 